\title{
Removal of organic matter from the underground water-a pilot scale technological research
}

\author{
Alina Pruss ${ }^{1}\left[\right.$ : Małgorzata Komorowska-Kaufman ${ }^{1} \cdot$ Paweł Pruss $^{2}$
}

Received: 16 December 2020 / Accepted: 30 August 2021 / Published online: 6 September 2021

(c) The Author(s) 2021

\begin{abstract}
The aim of the study was to select an appropriate technology for the treatment of groundwater with particular emphasis on the effectiveness of organic matter removal. The technological research was carried out on a pilot scale for 6 weeks. The pilot station was supplied with groundwater taken from two wells with different physical and chemical composition and mixtures of the two waters. The installation of the pilot station enabled different configuration of technological processes and continuous water sampling past each device. The following parameters were determined for the water samples: temperature, $\mathrm{pH}$, alkalinity, colour, turbidity, $\mathrm{COD} \mathrm{KMnO}_{4}$, TOC and dissolved oxygen, total and bivalent iron and manganese. On the basis of the analysis of the test results, it was found that the treatment technology based on natural aeration and rapid filtration processes was effective for water from well no. 2 and the mixtures of waters from well no. 1 and well no. 2, and the quality of treated water was in accordance with the limits specified in the Regulation of the Polish Minister of Health.
\end{abstract}

Keywords Organic matter · Groundwater · Technological research · Water treatment

\section{Introduction}

One of the important challenges for water treatment technologies is effective elimination of organic contaminants present in water in colloidal or diffuse form. Particular attention is paid to the removal of the fraction of biodegradable organic matter that is ubiquitous in aquatic ecosystems. This fraction includes a heterogeneous mixture of organic compounds with different physical and chemical properties, including humic and fulvic substances, proteins, amino acids, lipids, polysaccharides and biopolymers (Huber et al. 2011; Gilbert et al. 2013; Pruss 2015; Pruss and Pruss 2016a,b). The presence of the biodegradable fraction of

Alina Pruss

alina.pruss@put.poznan.pl

Małgorzata Komorowska-Kaufman

malgorzata.komorowska-kaufman@put.poznan.pl

Paweł Pruss

p.pruss@ aqua.poznan.pl

1 Faculty of Environmental Engineering and Energy, Institute of Environmental Engineering and Building Installations, Poznan University of Technology, Berdychowo 4, 60-965 Poznan, Poland

2 AQUA SA, Kanclerska 28, 60-327 Poznan, Poland organic matter in water may cause secondary development of microorganisms in the water supply network and thus deterioration of organoleptic properties of water directed to the consumer (Szuster-Janiaczyk 2016; Szuster-Janiaczyk and Bylka 2019). Biodegradable organic carbon is also a precursor of harmful by-products of the disinfection process (Włodyka-Bergier and Bergier 2011; Rosińska and Rakocz 2013; Wolska 2014; Hrudeys and Fawell 2015; WłodykaBergier et al. 2016; Liu et al. 2017; Domoń et al. 2018; Zimoch and Bartkiewicz 2018, 2019; Wolska et al. 2019).

Frequently, low $\mathrm{pH}$ value and high content of organic compounds contribute to high concentrations of iron in groundwater (Maziarka and Krogulska 2018). Organic substances present in water are classified into those of natural and anthropogenic origin. Natural organic substances include humic acids, fulvic acids, humines, products of microbial metabolism and compounds from the decomposition of dead animals and plants (Krupińska 2016a,b). Substances of anthropogenic origin include phenols, PAHs, surfactants, chlorinated organic compounds, oil derivatives and pesticides which are found in the leachate from landfills, fertilizers, sewage and plant protection products (Visco et al. 2005).

In groundwater treatment plants which rely on a typical, non-reagent technology, iron removal consists in oxidising 
dissolved iron (II) to a water-insoluble iron (III) by aeration. Iron (III) hydroxide is finally removed by sedimentation and filtration. That was the case in the treatment of water from well no. 2 (Fig. 6) during pilot studies described in this publication. Many WTPs are supplied with groundwater whose impurities prevent oxidation of iron with oxygen. Iron removal from groundwater is limited by organic substances as they form stable complexes with this element, both in bivalent and trivalent form (Krupińska 2017a,b). In this case, the use of aeration to oxidise iron (II) will not bring the expected results, because of the formation of colloidal and coloured ferro-organic compounds dissolved in water, which will increase the colour and turbidity of the treated water, and the stability of such compounds will increase with the rising concentration of organic ligands (Krupińska 2017a,b). Groundwater may be contaminated with humic compounds, which occur in dissolved, insoluble or colloidal form. In combination with iron, these substances form permanent complexes of different solubility and colloids. The stability of humic substances increases with the growing $\mathrm{pH}$ value. This causes an increase in the degree of dissociation of functional groups. A reverse situation occurs when the water reaction decreases. Lower $\mathrm{pH}$ contributes to decreasing the degree of dissociation of humic compounds and causes particle aggregation. The resulting colour of humic substances results from changes in the concentration of $\mathrm{H}+$ ions, which are the cause of changes in the structure of chromophore groups. According to many studies, it is probable that with the decrease in hydrogen ion concentration and an increase in the colour of groundwater, the content of humic acids is observed. Such a situation most likely occurred during the studies described in this article in the case of water taken from well no. 1 (Fig. 7). The consumption of water with basic humic compounds is not harmful to human health. However, it should be noted that these substances have the ability to adsorb other contaminants, often toxic, which are dangerous and unacceptable in water intended for human consumption and should therefore be removed. Treatment of water containing humic compounds requires the use of advanced technological systems. Organic substances should be removed before the disinfection process, as they are believed to contribute to the formation of by-products of this process (Kłosok-Bazan 2013; Szuster-Janiaczyk 2016; Szuster-Janiaczyk and Bylka 2019; Nhamo et al. 2020). The water quality parameters which indicate the presence of humic compounds in groundwater are colour, total organic carbon, oxidation and UV absorbance at $254 \mathrm{~nm}$ wavelength (Kaleta and Elektorowicz 2009).

In many studies described in the literature, methods of iron removal in combination with organic compounds are presented. These compounds cause extension of the oxidation time of $\mathrm{Fe}$ (II) to $\mathrm{Fe}$ (III), decrease its effectiveness and the products formed in this process are colloidal
(Albrektiene et al. 2011). The recommended method of removal is to use strong oxidants such as chlorine, potassium manganate (VII), ozone and hydrogen peroxide. The safety of the process should be taken into account so that no inorganic and organic by-products, which are harmful to human health, are produced during oxidation (Krupińska 2017a,b). Other processes that are used for the removal of humic compounds are: coagulation, filtration, sorption on active carbon together with biodegradation on biological active carbon filters, ion exchange and membrane processes. It has been proved that the most effective method of removing humic compounds is the coagulation process combined with filtration on active carbon.

According to Knocke et al. (1991), free chlorine, ozone and hydrogen peroxide are not completely effective in iron (II) oxidation when this element is combined with certain humic and fulvic acids. The author has proved that organic compounds with a higher molecular weight are more effective in protecting iron against oxidants. Moreover, the use of chlorine may lead to the formation of iron compounds in a colloidal form, which is not retained on filters. The use of chlorine compounds is also not recommended due to the danger of formation of chlorine organic compounds, including trihalomethanes. However, chemical oxidation with ozone or hydrogen peroxide may cause the fractionation of large organic particles into smaller ones (Krupińska 2017a,b). Indirect organic oxidation products of organic compounds that remain in water can stabilise iron. Sedimentation and filtration processes will not be sufficient to remove the created ferro-organic bonds (Krupińska et al. 2013).

Chemical oxidation of iron with potassium manganese (VII) is recommended when there are also manganese (II) compounds in groundwater. This process improves the adsorption and catalytic properties of precipitated manganese (IV) oxide. The oxidation reaction produces iron (III) hydroxide and manganese (IV) oxide, which acts as a catalyst for the oxidation of iron (II) and manganese (II). Catalytic oxidation of these ions allows for the use of smaller doses of potassium manganate (VII) (Krupińska 2017a,b).

The coagulation process is considered necessary to remove colloidal connections between iron and organic compounds. The efficiency of the process depends on the type and dose of coagulant and the co-occurrence factor of organic substances to total iron in untreated water (Krupińska 2017a,b). In the case of treatment of groundwater containing iron in combination with organic compounds, the oxidation of iron (II) ions is often required before the coagulation process. Using potassium (VII) manganese as an oxidant will most effectively reduce the colour, turbidity, concentration of manganese and organic compounds (Krupińska 2016a,b). Commonly used coagulants are iron and aluminium salts. In a study by Krupińska (2017a,b), popular coagulants were compared. The best results were 
obtained with polyglycol chloride, which removed iron compounds together with organic impurities causing too high colour and turbidity values of the tested water. The study was carried out on groundwater with high concentration of total iron and high content of organic substances. The analysed water was subjected to the coagulation process together with aeration. Thanks to such technological processes, the colour, turbidity and concentration of iron compounds were reduced. According to many researchers, iron coagulants are more effective in removing manganese and aluminium reagents in reducing the content of organic iron complexes. This is due to the fact that iron (III) ions or their hydrolysis products interact more strongly with organic compounds and form colourful complexes with them. According to Krupińska (2015), aluminium coagulants increase their effectiveness in removing organic and inorganic substances from water with an increase in the dose of reagents and temperature and a concurrent decrease in the value of organic substances and total iron. The coagulation process removes colloidal organo-iron compounds but does not affect the concentration of dissolved organo-iron compounds (Krupińska 2017a,b).

The effectiveness of coagulation combined with filtration was confirmed in the study carried out by Kłosok-Bazan (2013). Aeration, coagulation in the clarifier and filtration were applied. Hydrolysed aluminium polychlorosulphate was used as a coagulant. The water was characterized by high concentration of iron and the presence of organic compounds. In the experiment, a high effect of iron removal (75-90\%) and organic compounds (42-60\%) was obtained. Krupińska (2016a,b) also concluded in her paper that the most effective method of removing humic substances from water was the coagulation process combined with filtration on active carbon which allows to remove up to $80 \%$ of humic substances.

The sorption process used to remove humic substances from water is not perfect. When adsorbing large particles, there is a risk of blocking the adsorbent micropores. In order to increase the efficiency of the process, a chemical oxidation process should first be used to fractionate large organic compounds. The resulting compounds take the form of adsorption and biodegradation-prone compounds. The efficiency of the adsorption process depends on the type of adsorbent and $\mathrm{pH}$. Adsorption of humic compounds on active carbon is most effective at $\mathrm{pH} 5-7$. An increase in $\mathrm{pH}$ above 8 resulted in deterioration of the process efficiency (Kaleta et al. 2017). The study carried out by a research team from Poznań (Holc et al. 2019) showed that the use of biologically active filters in which sorption occurred was a very effective method of removing organic compounds from water. Tap water and water modified with humic compounds were tested. Filters with active carbon deposit allowed to achieve over $91 \%$ efficiency of organic compounds concentration reduction.
On the other hand, the research conducted by Krupińska (2015) showed that microbiological transformations played an important role in the treatment of groundwater containing iron with humic compounds. The transformations take place in filtration sludge, in which microorganisms are present. The activated granular carbon used as a filter material acts as an adsorbent of organic substances and a growth medium for organisms which participate in the oxidation of iron, manganese and organic substances. As a result of iron (II) oxidation, insoluble oxides and hydroxides are formed, which are retained on cellular organelles of microorganisms and activated carbon (Krupinska 2015).

The study conducted by Pietrzyk and Papciak (2018) assessed the effectiveness of organic compounds removal in the technological system consisting of aeration, coagulation, filtration on anthracite-sand deposits and biofiltration on activated granular carbon. Groundwater rich in organic compounds was purified in the range of $49-100 \%$ depending on the parameter. The following parameters were determined: dissolved organic carbon, particulate organic carbon and total organic carbon content. The process of coagulation resulted in a decrease in the content of organic compounds, which are responsible for the colour of water and the content of organic carbon in the form of particles. Elimination of organic substances which determine the UV absorbance value was guaranteed by filtration on sand and anthracite deposits. The process of biofiltration resulted in a reduction of all parameters indicating the presence of organic matter, i.e. colour, UV absorbance, total organic carbon content and water $\mathrm{COD} \mathrm{KMnO}_{4}$.

A pilot water treatment plant was installed in the city of Nida, Lithuania and used for tests which lasted 8 months. The groundwater was characterized by a high content of organic matter, iron, manganese and ammonium ions. The authors (Albrektiene et al. 2017) applied the following processes: open aeration, coagulation, a first stage filtration, closed aeration, second stage filtration and third stage filtration. The water flowed through the weirs in order to saturate it with oxygen and remove hydrogen sulphide. Then, polyglycol chloride was dosed into the water that was pumped to the first filtration stage. The reagent, together with the water, flowed through the reaction chamber where sludge was formed. The treatment water flowed to a pressure filter filled with quartz sand which was to reduce the concentration of iron and organic compounds. Then, the water flowed to a closed aerator, which enriched it with oxygen necessary for oxidation of manganese compounds and ammonium ions. The subsequent filters were filled with natural zeolite and quartz sand containing ammonium nitrogen oxidizing bacteria, respectively. The applied technology allowed for minimum coagulant consumption with high water treatment efficiency. The concentration of iron decreased by $98 \%$, of manganese by $87 \%$ and of ammonium nitrogen by $99 \%$. An 
$80 \%$ reduction in the concentration of organic compounds and water colour was achieved.

To sum up, in order to remove from groundwater iron which occurs in combination with organic compounds, it is necessary to apply preliminary oxidation and a coagulation process. Unfortunately, in many small water treatment plants, such processes are not viable; therefore, when there are several water intakes providing water of good quality, the aim is to eliminate the intakes with heavily polluted water or to determine the possible rate of mixing such water safely for a typical non-reagent technology. Such a solution is presented in this publication.

In the face of changing legal regulations, growing consumer demands and high costs of water production, water supply companies intending to build or modernize water treatment plants need effective support to safely determine the directions of project and investment activities. The overriding goal is to achieve the most advantageous water treatment technology in technological and economic terms. In the case of existing plants, pilot technology tests offer an economical method of testing alternative and often innovative technologies without affecting the existing water treatment process. They are useful in developing changes in the existing water treatment process in order to improve water quality and/or reduce water production costs. The possibility to test alternative processes independently of those implemented on a technical scale is particularly valuable. The right approach to the topic is to perform pre-design technological research to determine the water treatment technology, parameters of individual processes and the necessary scope of investment. The result of technological research is the knowledge of the proper technological system, approximate investment and operating costs of the investment. Designers are provided with guidelines which enable the proper execution of technical documentation. A well-thought-out construction and execution project allows for proper implementation of the investment, which will be completed by launching and receiving the investment and achieving the intended technological effect (Pruss and Pruss 2010, 2016a,b; Pruss 2015).

Existing plant works with processes and equipment as follows: groundwater from wells is pumped to buffer tank with chemical oxidation by potassium permanganate before. Next step is filtration in 6 continuous sand filters. After filtration, water is disinfected by UV ray and sodium hypochlorite. In this plant, removal of manganese is insufficient and unstable. Other problem are organic compounds, not removed in process, which causes high disinfectant demand and impossibility to use one of existing well. Water from this protective well has to be wasted because of high concentration of organic compounds.

The aim of the research presented in this article was to select an economic and environmentally friendly nonreagent technology of groundwater treatment other than the one used so far on WTP with particular emphasis on the effectiveness of organic matter removal. An attempt was also made to treat water from a protective well which had not previously been used for water production. In addition, safe mixing ratios of water from the protection well with water from other wells were established for the proposed non-reagent groundwater treatment technology. The results were used to prepare the concept of a new groundwater treatment plant.

\section{Methods and materials}

\section{Pilot water treatment plant (WTP)}

The pilot WTP was operated at the capacity of $2800-3000$ $\mathrm{L} / \mathrm{h}$. The test stand consisted of an aerator for water aeration, two contact tanks, a multi-stream settling tank and three filter columns working in parallel. The flow rate of water flowing to the aerator, the settling tank and filtration columns, depending on the needs, was regulated by using rotameters installed before each of the abovementioned devices (Fig. 1).

The water taken directly from the well was fed to the research installation and directed to the first device of the process line which was the aerator. Due to the characteristics of raw water, in particular the occurrence of the alkaline aspiration compounds in the intake water, the use of open aeration was proposed (water pumped into air) with a contact chamber. The aerator was a high-socket column of about $2.5 \mathrm{~m}$ made of acid-resistant steel consisting of five segments in which the water grids were placed. Raw water flowed from the top into the inlet chamber of the aerator and then flowed successively through five segments of the device (Fig. 2). In the lowest segment, through openings placed in the wall of the aerator segment, the water flowed out to a tray where it was aerated and degassed and then flowed down by gravity into the reaction chambers (Fig. 3). Due to quite high concentrations of iron in the groundwater, the use of a contact chamber past the water aeration process was proposed, optionally with a multi-stream settling tank (Fig. 4). In order to ensure effective de-ironing across the whole thickness of the bed, the time of water contact between the water and the air was experimentally determined so that at the moment of reaching the filtration bed, the $\mathrm{Fe}(\mathrm{III})$ content in water was $30-50 \%$ of the total $\mathrm{Fe}$ content. The optimal contact time between aerated water and dissolved oxygen was determined at the beginning of the pilot studies using aerated water sampled directly after aeration.

Typical $1000 \mathrm{~L}$ and $600 \mathrm{~L}$ tanks were used as reaction chambers. The testing installation allowed to operate both tanks simultaneously or each of them separately. Such a configuration of the reaction chambers enabled the entire station to operate at different contact times. In the installation, it 


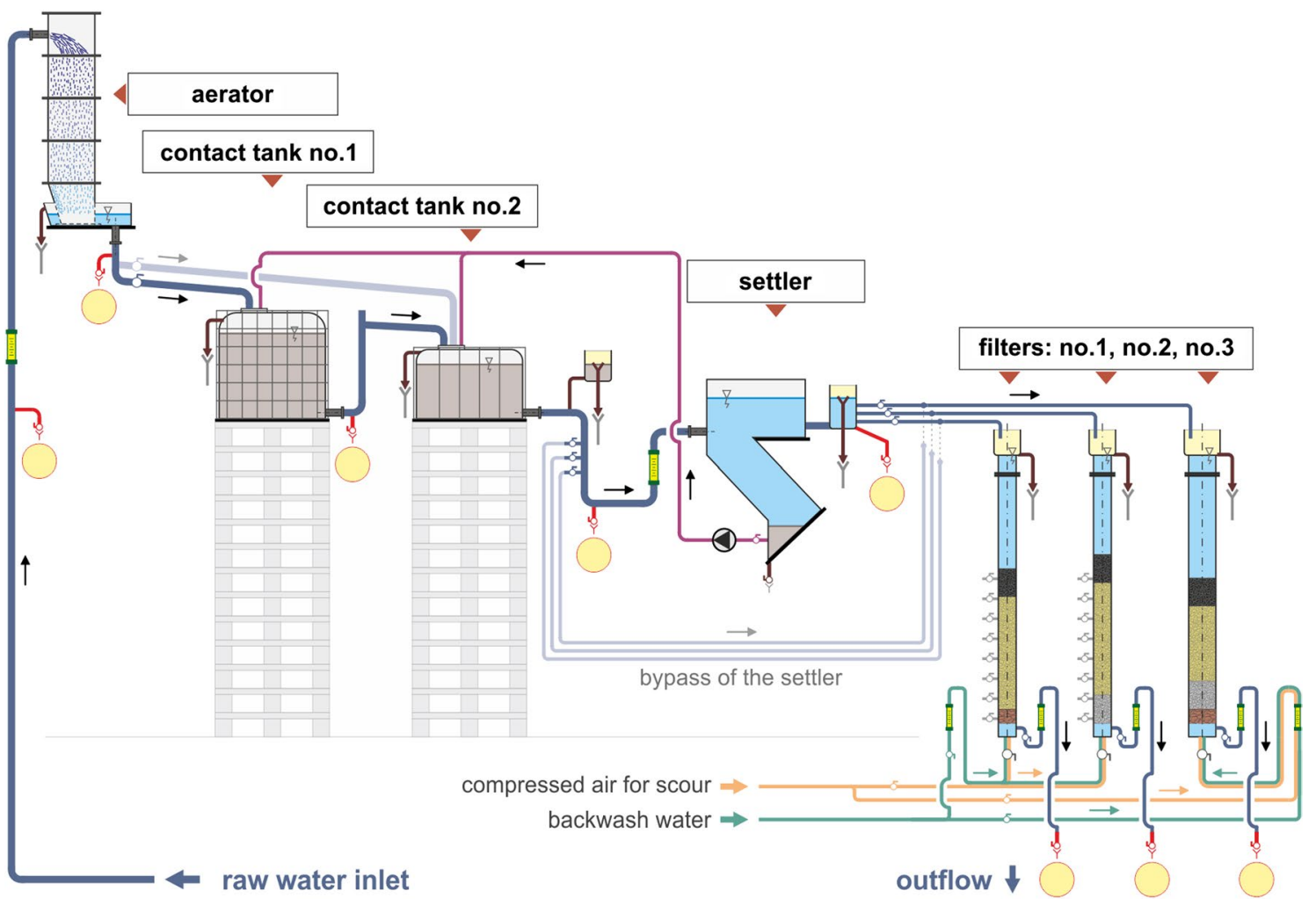

Fig. 1 The diagram of the pilot station technology

was also possible to omit the reaction chambers and pump the aerated water directly to the settling tank or to the filters. The results of the tests presented in this article concern the operation of the pilot WTP with the use of the reaction chambers and the multi-stream settling tank. The water retention time in the reaction chambers was $10 \mathrm{~min}$ for water from well no. 1 and about 18 min for water from well no. 2 and the mixtures of the two waters.

Past the reaction chambers water flowed into the settling tank. A multi-stream settling tank was used in the research. During the tests, the flow rate of water directed to the settling tank was $150 \mathrm{~L} / \mathrm{h}$. The water from the outlet chamber of the settling tank was directed to rapid filters, while the sludge was directed to a sludge hopper.

The pilot station had three filter columns. The filtration rate was $5 \mathrm{~m} / \mathrm{h}$. At the beginning, two filtration columns made of polymethyl methacrylate pipes with a diameter of $0.094 \mathrm{~m}$ and a height of $3.0 \mathrm{~m}$ were operated. In both filtration columns, the bed height was $1.5 \mathrm{~m}$. In the first filtration column, a $120 \mathrm{~cm}$ filter bed of quartz sand $(0.71-1.25 \mathrm{~mm}$; $\mathrm{WR}<1.5)$ and $30 \mathrm{~cm}$ filter bed of anthracite $(1.4-2.5 \mathrm{~mm}$; $\mathrm{WR}<1.5)$ were used. The second column was filled with $30 \mathrm{~cm}$ of G-1 catalytic mass layer $(1.0-3.0 \mathrm{~mm})$ and $120 \mathrm{~cm}$ of quartz sand filter bed $(0.71-1.25 \mathrm{~mm}$; WR $<1.5)$. The third filtration column was $0.2 \mathrm{~m}$ in diameter and $4.0 \mathrm{~m}$ high. It was filled with a $1.55 \mathrm{~m}$ high filter bed consisting of the following layers $15 \mathrm{~cm}$ gravel support layer, $30 \mathrm{~cm}$ G-1 catalytic mass layer $(1.0-3.0 \mathrm{~mm}), 60 \mathrm{~cm}$ filter bed of quartz sand $(0.71-1.25 \mathrm{~mm}$; WR $<1.5), 20 \mathrm{~cm}$ of quartz sand filtration bed $(0.1-1.25 \mathrm{~mm} ; \mathrm{WR}<1.5)$ and $30 \mathrm{~cm}$ of anthracite filter bed $(1.4-2.5 \mathrm{~mm}$; WR $<1.5)$.

The signal to backwash the filters was a pressure loss of $200 \mathrm{~cm}$ or a bed breakage (presence of $\mathrm{Fe}$ in the outlet). The filter bed was backwashed with air and water at an intensity ensuring $30 \%$ expansion.

\section{Water samples analysis}

Water for analyses was taken past each device installed in the pilot WTP. The sampling points are marked on Fig. 1. The studies were carried out for four types of groundwater: water from well no. 1, water from well no. 2 and a mixture of the two waters containing $27 \%$ and $18 \%$ of water from well no. 1 . The average quality of water entering the pilot WTP is shown in Table 1. Well no. 1 is a protective well and its water is not currently treated, but due to hydrogeological recommendations in order to properly operate the remaining wells, water must be taken from it.

The regular analytical tests (every $24 \mathrm{~h}$ ) included: temperature, $\mathrm{pH}$, alkalinity, turbidity, colour, smell, dissolved oxygen, redox potential, total and bivalent iron, manganese, $\mathrm{COD} \mathrm{KMnO}_{4}$ and periodically TOC. All analyses 


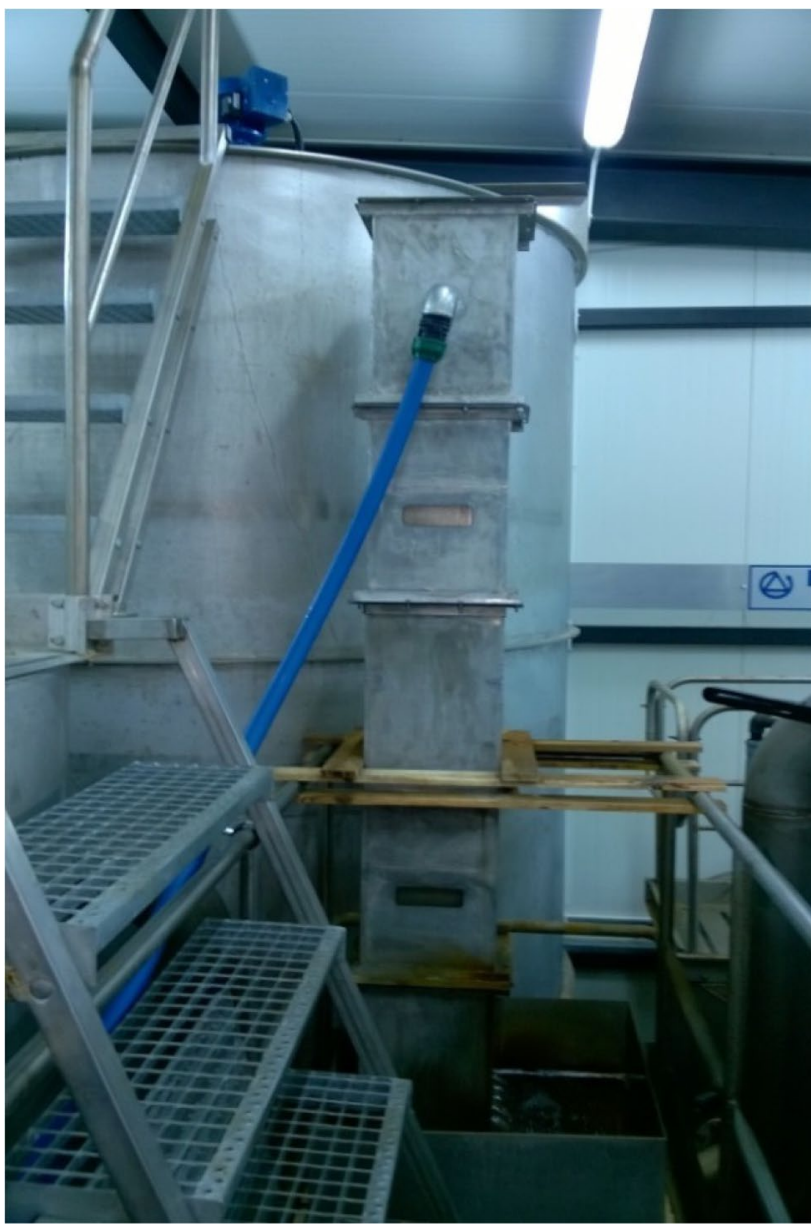

Fig. 2 Aerator for water aeration

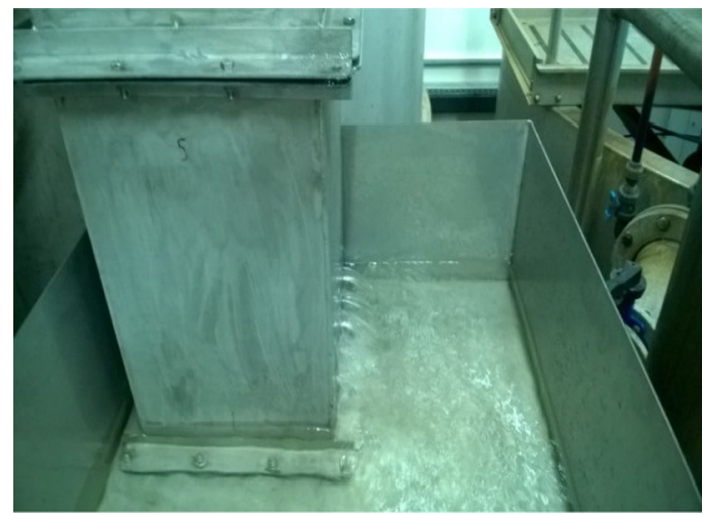

Fig. 3 Last segment of the aerator with aerated water outflow

were performed in accordance with the Standard Methods. Detailed information on the steps to be taken to select the appropriate configuration of the pilot groundwater treatment plant and the benefits of carrying out the pilot studies are described in the publication (Pruss et al. 2018).

\section{Results and discussion}

Figures 5, 6, 7 and 8 show changes in $\mathrm{COD} \mathrm{KMnO}_{4}$, total iron, iron II and $\mathrm{pH}$ of water from well no. 1, no. 2 and the mixtures of the two waters in different proportions during treatment in the technological system of the pilot WTP.

The water taken from well no. 1 was characterized by a high organic matter content, i.e. COD $\mathrm{KMnO}_{4}$ of $14.77 \mathrm{mg}$ $\mathrm{O}_{2} / \mathrm{L}$ on average and TOC at $6.9 \mathrm{mg} \mathrm{C} / \mathrm{L}$. The $\mathrm{pH}$ of raw water was at the level of 7.1. In the treatment process based on classical non-reagent technology of groundwater treatment, the aim was to reduce the concentration of organic substances present in the water as a result of coprecipitation with Fe III. However, observing the results of the studies (Fig. 5), it can be seen that lowering the concentration of organic matter was very difficult. This was probably due to the co-occurrence of humic compounds and iron in water. The water from well no. 1 was characterized by an intensive brown colour, which would confirm the assumptions. The water past filter no. 1 had an average $\mathrm{COD} \mathrm{KMnO}_{4}$ of about $10.53 \mathrm{mg} \mathrm{O}_{2} / \mathrm{L}$, while the water past filter no. $2 \mathrm{had}$ an average COD $\mathrm{KMnO}_{4}$ of $9.82 \mathrm{mg} \mathrm{O}_{2} / \mathrm{L}$ with the simultaneous substitution of iron II. The results of the analysis of total iron and iron II confirm that about $30 \%$ of iron II present in the raw water was not oxidized. Therefore, the proposed treatment technology can certainly be considered to have failed for the water from well no. 1 which is difficult to treat. Humic substances include humic acids, hymatomelanic acids and fulvic acids. They cause strong colouring of water. The colour ranges from brown to black. Their presence does not directly affect human health, however, as they are precursors of disinfection by-products and thanks to complexing of heavy metals and adsorption of toxic organic substances, their removal is necessary during the production of water intended for human consumption. The presence of organic compounds in connection with iron in groundwater can make its treatment much more difficult. This is due to the fact that iron in humic compounds is more difficult to oxidise than $\mathrm{Fe}(\mathrm{OH})_{2}$ because the organic substance has to be melted first and only then can Fe(II) be oxidised to Fe(III) (Kłosok-Bazan 2013; Krupinska 2015, 2016a,2017a; b, b).

Raw water from well no. 2 compared to well no. 1 had a much lower organic content, i.e. $\mathrm{COD} \mathrm{KMnO}_{4}$ was $3.9 \mathrm{mg}$ $\mathrm{O}_{2} / \mathrm{L}$ on average, while the TOC was $4.2 \mathrm{mg} \mathrm{C} / \mathrm{L}$ and the content of iron was similar. The $\mathrm{pH}$ of raw water was at the level of 7.1. Based on the test results (Fig. 6), a decrease in organic matter concentration can be observed. The 
Fig. 4 Pilot station-two reaction chambers (chamber no. 1 filled with water) and a multistream settling tank

Table 1 The average groundwater quality

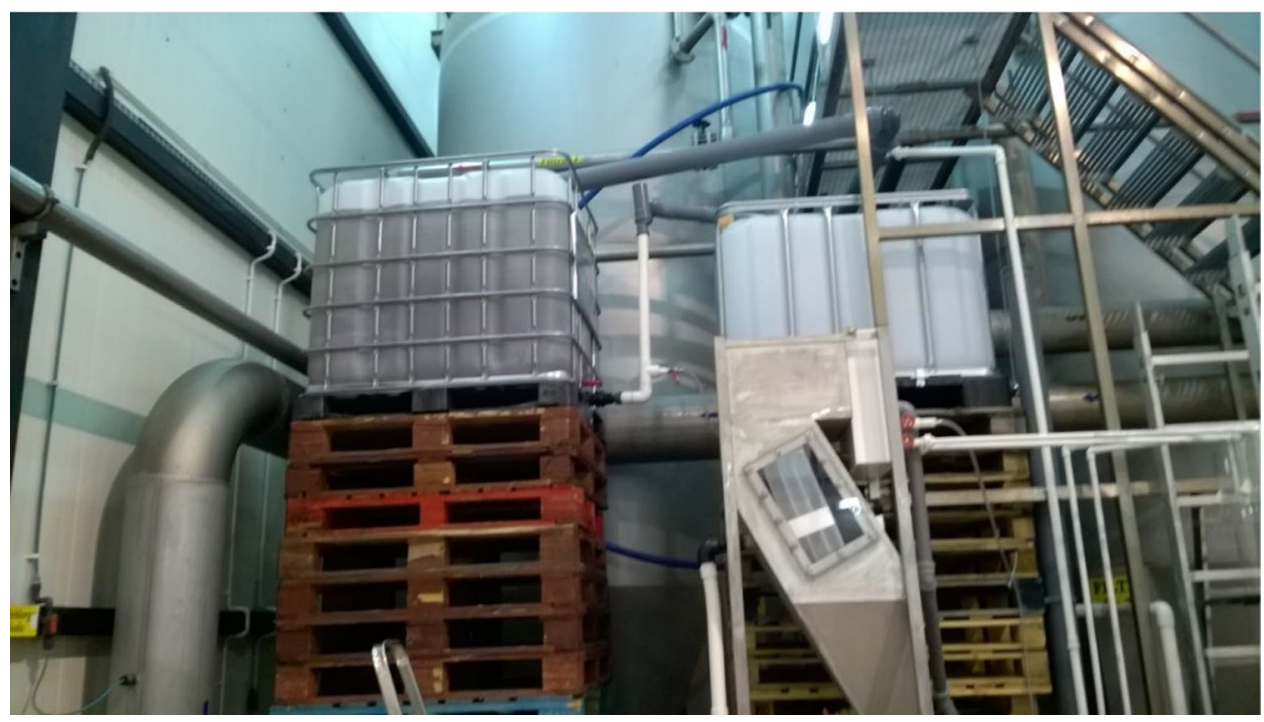

\begin{tabular}{llllll}
\hline Parameter & Unit & Well no. 1 & Well no. 2 & $27 \%$ Well no. 1 & $18 \%$ Well no. 1 \\
\hline Temperature & ${ }^{\circ} \mathrm{C}$ & $11.7 \pm 0.3$ & $11.5 \pm 0.4$ & $11.8 \pm 0.7$ & $10.9 \pm 0.3$ \\
Smell & {$[-]$} & $4 \mathrm{G} \mathrm{H}_{2} \mathrm{~S}$ & $3 \mathrm{G} \mathrm{H}_{2} \mathrm{~S}$ & $3 \mathrm{G} \mathrm{H}_{2} \mathrm{~S}$ & $3 \mathrm{G} \mathrm{H}_{2} \mathrm{~S}$ \\
Colour & $\mathrm{mgPt} / \mathrm{L}$ & $18 \pm 4$ & $27 \pm 6$ & $29 \pm 7$ & $27 \pm 9$ \\
Turbidity & $\mathrm{NTU}$ & $3.6 \pm 1.2$ & $1.5 \pm 0.7$ & $3.6 \pm 2.9$ & $4.2 \pm 2.5$ \\
$\mathrm{pH}$ & {$[-]$} & $7.11 \pm 0.03$ & $7.14 \pm 0.07$ & $7.15 \pm 0.11$ & $7.14 \pm 0.01$ \\
Total iron & $\mathrm{mgFe} / \mathrm{L}$ & $4.1 \pm 0.06$ & $4.0 \pm 0.05$ & $4.0 \pm 0.06$ & $4.0 \pm 0.07$ \\
Divalent iron & $\mathrm{mgFe} / \mathrm{L}$ & $4.1 \pm 0.06$ & $4.0 \pm 0.05$ & $4.0 \pm 0.06$ & $4.0 \pm 0.07$ \\
Manganese & $\mathrm{mgMn} / \mathrm{L}$ & $0.15 \pm 0.05$ & $0.14 \pm 0.05$ & $0.13 \pm 0.07$ & $0.15 \pm 0.03$ \\
Alkalinity & $\mathrm{mval} / \mathrm{L}$ & $7.0 \pm 0.08$ & $7.0 \pm 0.28$ & $7.0 \pm 0.08$ & $7.15 \pm 0.07$ \\
Dissolved oxygen & $\mathrm{mgO} / \mathrm{L}$ & $0.25 \pm 0.18$ & $0.2 \pm 0.10$ & $0.3 \pm 0.2$ & $0.3 \pm 0.09$ \\
The redox potential & $\mathrm{mV}$ & $-20 \pm 1$ & $-32 \pm 7$ & $-21 \pm 8$ & $-26 \pm 0.7$ \\
COD KMnO & $\mathrm{mgO} / \mathrm{L}$ & $14.77 \pm 2.0$ & $4.2 \pm 0.3$ & $5.6 \pm 0.7$ & $4.73 \pm 0.5$ \\
TOC & $\mathrm{mgCl}_{4}$ & $6.9 \pm 0.0$ & $4.2 \pm 0.2$ & $4.5 \pm 1.0$ & $4.3 \pm 0.0$ \\
\hline
\end{tabular}

Fig. 5 Changes in the COD $\mathrm{KMnO}_{4}$, TOC, iron and $\mathrm{pH}$ of water from well no. 1 during its treatment in technological processes of the pilot WTP

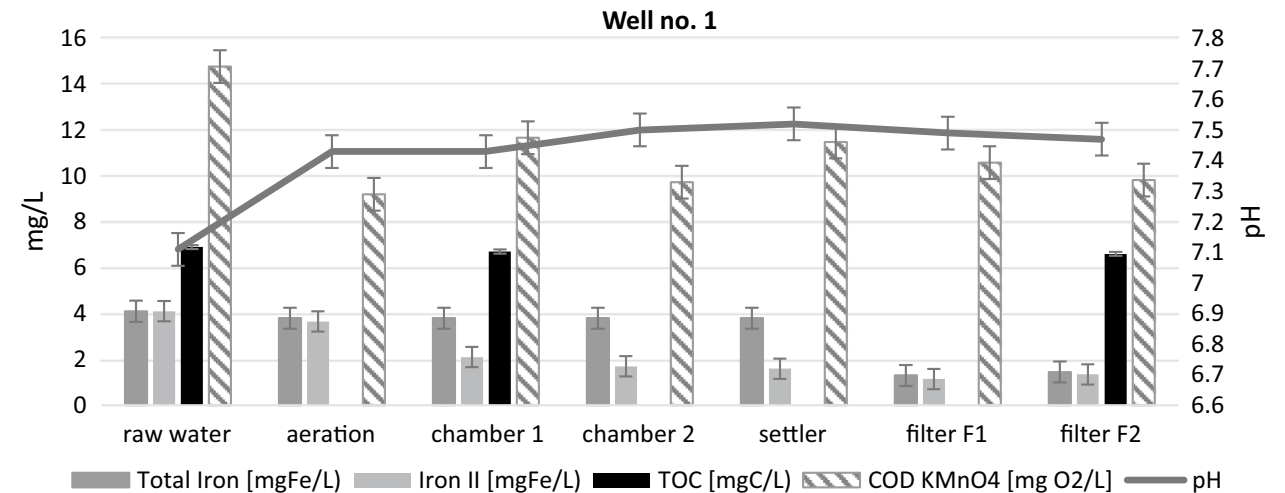

water past filter no. 2 had a COD $\mathrm{KMnO}_{4}$ of $3.3 \mathrm{mg} \mathrm{O} / \mathrm{L}$ on average, while the water past filter no. 3 had a COD $\mathrm{KMnO}_{4}$ of $2.88 \mathrm{mg} \mathrm{O}_{2} / \mathrm{L}$. The TOC on the outlet of filter 2 was $3.6 \mathrm{mg} \mathrm{C} / \mathrm{L}$ and on the outlet of filter 3 approximately
$3.3 \mathrm{mg} \mathrm{C} / \mathrm{L}$. It should be noted that the concentration of total iron on the outlet of filter no. 2 was $0.09 \mathrm{mg} \mathrm{Fe} / \mathrm{L}$ and of filter no. 3 was $0.08 \mathrm{mg} \mathrm{Fe} / \mathrm{L}$, which confirmed that the 
Fig. 6 Changes in the COD $\mathrm{KMnO}_{4}$, TOC, iron and $\mathrm{pH}$ of water from well no. 2 during its treatment in technological processes of the pilot WTP
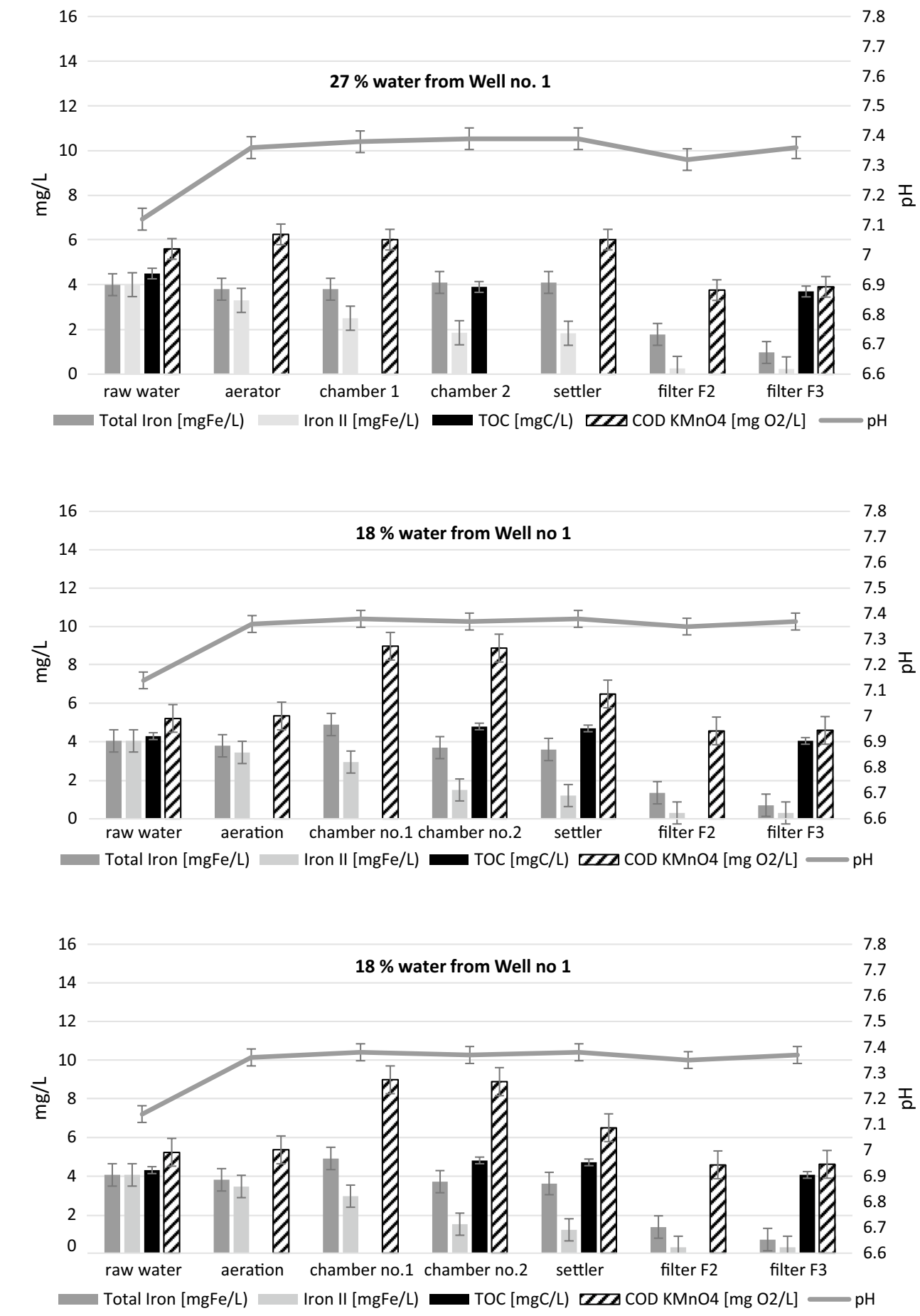

Fig. 7 Changes in the COD $\mathrm{KMnO}_{4}$, TOC, iron and $\mathrm{pH}$ of mixed water from both wells with $27 \%$ of water from well no. 1 during its treatment in technological processes of the pilot WTP
Fig. 8 Changes in the COD $\mathrm{KMnO}_{4}, \mathrm{TOC}$, iron and $\mathrm{pH}$ of mixed water from both wells with a $27 \%$ share of water from well no. 1 during its treatment in technological processes of the pilot WTP iron present in water from well no. 2 was not combined with organic compounds.

The analysis of changes in $\mathrm{COD} \mathrm{KMnO}_{4}$, TOC and iron in the mixed water from both wells with a $27 \%$ share of water from well no. 1 shows a significant decrease in the achieved results of water treatment in the proposed process line (Fig. 7). Only in the last stage of the water treatment process, i.e. filtration through filter bed 3 , the observed concentrations of organic substances were in accordance with the guidelines specified in the Regulation of the Polish Minister of Health of 2017, i.e. the average COD $\mathrm{KMnO}_{4}$ value of the treated water was $4.52 \mathrm{mg} \mathrm{O}_{2} / \mathrm{L}$ and TOC was $3.95 \mathrm{mg}$ $\mathrm{C} / \mathrm{L}$. The average concentration of total iron in the water past filter no. 3 was $0.97 \mathrm{mg} \mathrm{Fe} / \mathrm{L}$, of which the concentration of $\mathrm{Fe}(\mathrm{II})$ was $0.23 \mathrm{mg} \mathrm{Fe} / \mathrm{L}$.

The increase in $\mathrm{COD} \mathrm{KMnO}_{4}$ of the water in the process line past the reaction chambers, as shown in Fig. 8, was most probably related to the leaching of sludge from the reaction 
chambers. The average $\mathrm{COD} \mathrm{KMnO}_{4}$ of the water mixture flowing into the pilot station was $5.2 \mathrm{mg} \mathrm{O}_{2} / \mathrm{L}$ with an average reaction rate of 7.14. The efficiency of organic matter concentration reduction during the whole process was only $7 \%$ for TOC and $12 \%$ for COD $\mathrm{KMnO}_{4}$. Iron was reduced on average by $72 \%$. In the treated water, the average TOC value was $4.0 \mathrm{mg} \mathrm{C} / \mathrm{L}, \mathrm{COD} \mathrm{KMnO}_{4}$ was $4.6 \mathrm{mg} \mathrm{O}_{2} / \mathrm{L}$, the concentration of total iron was $0.7 \mathrm{mg} \mathrm{Fe} / \mathrm{L}$ and the concentration of $\mathrm{Fe}(\mathrm{II})$ was $0.3 \mathrm{mg} \mathrm{Fe} / \mathrm{L}$. The results indicated the possibility of achieving iron concentration values consistent with the Regulation of the Polish Minister of Health by increasing the filtration efficiency. The desired iron removal efficiency was obtained by adding a $20 \mathrm{~cm}$ layer of quartz sand with less granulation than previously applied ( 0.63 to $1.0 \mathrm{~mm}$ granulation) to filter 3 . In the last filtration cycle carried out after sealing the bed of filter 3, iron concentrations below $0.2 \mathrm{mg} \mathrm{Fe} / \mathrm{L}$ were obtained in the filter.

In the analyzed technological line of the pilot water treatment plant, the manganese content was lowered in the filtration process. It should be emphasized that on the rapid filters, satisfactory manganese removal effects were obtained for each of the tested water. The tests showed that in filters with a catalytic layer (filter no. 2 and 3), manganese was removed to values close to $0.0 \mathrm{mgMn} / \mathrm{L}$.

In the case of both analysed water mixtures, the effect of lowering the concentration of organic compounds present in water to values consistent with the guidelines given in the Regulation of the Polish Minister of Health of 2017 was achieved. Iron concentration in mixed waters from both wells was significantly reduced as a result of the applied technological processes and it was only by sealing the filter no. 3 that the iron concentration compliant with the requirements for water for human consumption could be obtained. It should be emphasized that in order to achieve the targeted effect, water from well no. 2 should be treated with a small addition of water from well no. 1, not exceeding $20 \%$.

\section{Conclusions}

Technological research carried out on a pilot scale is the best way to select appropriate water treatment technology. The testing installation met all the necessary criteria of hydraulic and technological similarity to the installation on the technical scale which is the subject of the future project. This guarantees identical quality of treated water both on a pilot and technical scale.

The research has shown that water from well no. 2 and a mixture of waters from well no. 2 and well no. containing maximum $20 \%$ of water from well no. 1 can be effectively treated with the use of the technology based on natural aeration and rapid filtration processes. Such a technology will ensure the achievement of drinking water quality parameters consistent with the guidelines specified in the Regulation of the Polish Minister of Health.

Pilot studies have shown that more advanced technological systems are needed to treat water from well no. 1, which is characterized by high content of organic substances (most probably humic compounds).

Acknowledgements The research was carried out within the framework of industrial Project 01/13/PRJG/0845 "Technological research aimed at determining the treatment processes of groundwater supplying WTP Joanka" and Poznan University of Technology research project 504101/0713/SBAD/0936 "Removal of organic matter from water in water treatment processes".

Author contributions AP designed and supervised the project, performed part of the experiments from this review, analyzed the data and wrote this paper. MK-K performed part of the experiments from this review, analyzed the data and wrote this paper. PP design and construction of a pilot research station; the concept of the research.

Funding The research was funded by the Industrial Project No. 01/13/ PRJG/0845 "Technological research aimed at determining the treatment processes of groundwater supplying WTP Joanka" and PUT Research Project 504101/0713/SBAD/0936.

\section{Declarations}

Conflict of interest The authors declare no conflict of interest. The funders had no role in the design of the study; in the collection, analyses or interpretation of data; in the writing of the manuscript and in the decision to publish the results.

Open Access This article is licensed under a Creative Commons Attribution 4.0 International License, which permits use, sharing, adaptation, distribution and reproduction in any medium or format, as long as you give appropriate credit to the original author(s) and the source, provide a link to the Creative Commons licence, and indicate if changes were made. The images or other third party material in this article are included in the article's Creative Commons licence, unless indicated otherwise in a credit line to the material. If material is not included in the article's Creative Commons licence and your intended use is not permitted by statutory regulation or exceeds the permitted use, you will need to obtain permission directly from the copyright holder. To view a copy of this licence, visit http://creativecommons.org/licenses/by/4.0/.

\section{References}

Albrektiene R, Rimeika M, Lubyte E (2011) The removal of ironorganic complexes from drinking water using coagulation process. Vilnius Gediminas Technical University

Albrektiene R, Rimeika M, Tamulaitiene B, Voisniene V (2017) Technology for treatment of groundwater simultaneously containing iron, manganese, ammonium and organic matter. J Water Supply Res Technol-Aqua

Domoń A, Papciak D, Tchórzewska-Cieślak B, Pietrucha-Urbanik K (2018) Biostability of tap water-a qualitative analysis of health risk in the example of groundwater treatment (semi-technical scale). Water 10(12), No 1764

Gilbert O, Lefevre B, Fernandez M, Bernat X, Paraira M, Calderer M, MartinezLlado X (2013) Charakterizing biofilm development

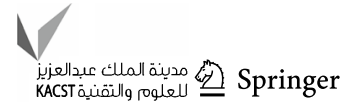


on granular activated carbon used for drinking water production. Water Res 135:207-219

Holc D, Pruss A, Komorowska-Kaufman M (2018) The possibility of using UV absorbance measurements to interpret the results of organic matter removal in the biofiltration process. Annu Set Environ Protect 20:326-341

Holc D, Pruss A, Komorowska-Kaufman M, Mądrecka B, Cybulski Z (2019) The sorption of organic compounds from water during technological start-up of carbon filters. E3S Web of Conferences, 100, 00027. EDP Sciences

Hrudeys E, Fawell J (2015) 40 years on: What do we know about drinking water disinfection by-products (DBPs) and human health? Water Sci Technol Water Supply 15:667-674

Huber S, Balz A, Abert M, Pronk W (2011) Characterization of aquatic humic and non-humic matter with size-exclusion chromatography — organic carbon detection — organic nitrogen detection (LCOCD-OND). Water Res 45:879-885

Kaleta J, Elektorowicz (2009) Removal of humic substances from aqueous solutions by the coagulation process. Environ Technol

Kaleta J, Puszkarewicz A, Papciak D (2017) Evaluation of the effectiveness of the adsorption process for the removal of humic substances from water. Inżynieria Ekologiczna-in Polish

Kłosok-Bazan I (2013) Removal of organically bound iron from groundwater. Ekonomia i Środowisko-in Polish

Knocke WR, Van Benschoten JE, Kearney MJ, Soborski AW, Reckhow DA (1991) Kinetics of manganese and iron oxidation by potassium permanganate and chlorine dioxide. Journal American Water Works Association, 1991

Krupinska I (2015) Effect of temperature and pH on the effectiveness of pollutant removal from groundwater in the process of coagulation. Ochrona Srodowiska 37(3):35-42

Krupińska I (2016a) The influence of aeration and type of coagulant on effectiveness in removing pollutants from groundwater in the process of coagulation. Chem Biochem Eng Q 30(4):465-475

Krupińska I (2016b) The impact of the oxidising agent type and coagulant type on the effectiveness of coagulation in the removal of pollutants from underground water with an increased content of organic substances. J Environ Eng Landsc Manag 24:70-78

Krupińska I (2017a) Effect of organic substances on the efficiency of $\mathrm{Fe}(\mathrm{II})$ to $\mathrm{Fe}$ (III) oxidation and removal of iron compounds from groundwater in the sedimentation process. Civ Environ Eng Rep 26(3):15-29

Krupińska I (2017b) The impact of potassium manganate (VII) on the effectiveness of coagulation in the removal of iron and manganese from groundwater with an increased content of organic substances. Civ Environ Eng Rep 27(4):29-41

Krupińska I, Kowalczyk W, Szczepaniak G (2013) Effect of coexistence ratio of organic substances and total iron in groundwater on its treatment efficacy. Ochrona Srodowiska 35(3):27-34

Liu C, Olivares CI, Pinto AJ, Lauderdale CV, Brown J, Selbes M, Karanfil T (2017) The control of disinfection byproducts and their precursors in biologically active filtration processes. Water Res $124: 630-653$

Maziarka D, Krogulska B (2018) Iron in water intended for human consumption. Główny Inspektorat Sanitarny—in Polish

Nhamo C, Savia SM, Welldone M, Nosibusiso M, Limakatso CT, Thomas I, Bhekie BM, Peter J, Thabo TI (2020) Contemporary issues on the occurrence and removal of disinfection byproducts in drinking water-a review. J Environ Chem Eng 8(2):103659. https://doi.org/10.1016/j.jece.2020.103659

Pietrzyk and Papciak (2018) The effectiveness of organic matter removal in unit processes of the technological groundwater treatment system E3S Web of Conferencess, Vol 44, p 00142. https://www.e3sconferences.org/articles/e3sconf/abs/2018/19/ e3sconf_eko-dok2018_00142/e3sconf_ekodok2018_00142.html

Pruss A (2015) Selection of the surface water treatment technology - a full scale technological investigation. Water Sci Technol 71(4):638-644

Pruss P, Pruss A (2010) Underground water treatment plant from technological research to its commissioning. Gas Water Sanit Technol 11:16-21

Pruss A, Pruss P (2016) The role of technological research in the investment process, Instal, No. 7-8, pp 62-65

Pruss A, Pruss P (2016b) An attempt at application of powdered activated carbon and selective anionite to increase effectiveness of organic matter elimination from water after coagulation process. Ochrona Srodowiska 38(1):25-28

Pruss P, Pruss A, Komorowska-Kaufman M (2018) Configuration of a pilot station in a technological investigation of groundwater treatment. EKO-DOK, E3S Web of Conferences 44, 00148, 2018. https://doi.org/10.1051/e3sconf/20184400148

Regulation of the Polish Minister of Health on quality intended for human consumption, Dz. U. 2017, item 2294

Rosińska A, Rakocz K (2013) The role of the biodegradable organic matter in the water disinfection. Inżynieria i Ochrona Środowiska 4:511-521-in Polish

Szuster-Janiaczyk A (2016) The microbiological evaluation of deposits come from water network on the example of selected water supply system. Annu Set Environ Prot 18(2):815-827

Szuster-Janiaczyk A, Bylka J (2019) The effect of the mixing of water from different sources in the water supply system on tap water quality - a full-scale technical investigation case study. Water Sci Technol Water Supply 19(1)

Visco G., Campanella L, Nobili V (2005) Organic carbons and TOC in waters: an overview of the international norm for its measurements, Microchem J

Włodyka-Bergier A, Bergier T (2011) Influence of organic matter quality on the formation potential of volatile organic products of water chlorination. Arch Environ Prot 37:25-35

Włodyka-Bergier A, Bergier T, Kowalewski Z, Grygar M (2016) Influence of modernization of disinfection method on drinking water microbial stability in Raba water distribution system in Krakow. Pol J Environ Stud 25:96-99

Wolska M (2014) Removal of precursors of chlorinated organic compounds in selected water treatment processes. Desalin Water Treat 52:3938-3946

Wolska M, Urbanska-Kozłowska H, Mołczan M (2019) Introduction of an adsorption process into a surface water treatment system and its effect on disinfectant use. Water Sci Technol Water Supply 19(5):1354-1362

Zimoch I, Bartkiewicz E (2018) Analysis of disinfectant decay in a water supply system based on mathematical model. Desalin Water Treat 134:272-280

Zimoch I, Bartkiewicz E (2019) Simulation modeling of chlorine content variation in water for different operating conditions of the water distribution system. Ochrona Środowiska 41(1):17-22

Publisher's Note Springer Nature remains neutral with regard to jurisdictional claims in published maps and institutional affiliations. 